\title{
Mechanism of normal menstruation and abnormality associated with menorrhagia
}

Jeanne Adiwinata Pawitan

\begin{abstract}
Abstrak
Pada haid nonnal terjadi peluruhan jaringan endometrium dan perdarahan, diikuti oleh hemostasis dan 'repair'. Kelainan dapat terjadi pada berbagai tahap dari proses di atas, dan dapat mengakibatkan perubahan jumlah darah haid. Haid dengan jumlah darah lebih dari $80 \mathrm{ml}$ disebut menorhagia. Sari pustaka ini membicarakan mekanisme haid normal, dan berbagai faktor yang berkaitan dengan menorhagia. Faktor tersebut adalah 'endometrial bleeding associated factor (ebaf)', peran berbagai sel (lekosit migran, makrofag, dan sel mast), peran berbagai zat (enzim lisosom, berbagai prostaglandin, endotelin, faktor pertumbuhan, dan reseptornya), gangguan pada fibrinolisis dan proses hemostasis, dan perubahan aliran darah endometrium. (Med J Indones 2001; 10: 121-6)
\end{abstract}

\begin{abstract}
Normal menstruation involves endometrial tissue breakdown and bleeding, followed by hemostasis and repair. Abnormality of this process at any stage may result in changes in the quantity of menstrual blood loss. When menstrual blood loss is greater than 80 ml, it is called menorrhagia. This review discuss the mechanism of normal menstruation, and factors associated with menorrhagia. Those factors are the endometrial bleeding associated factor (ebaf), the role of various cells (migratory leucocytes, macrophages, and mast cells), the role of various substances (lysosomal enzymes, prostaglandins, endothelins, growth factors and its receptors), impairment of fibrinolysis and hemostatic proces, and changes in endometrial blood flow. (Med J Indones 2001; 10: 121-6)
\end{abstract}

Keywords: ebaf, prostaglandin, endothelin, fibrinolysis

Nomal menstruation involves endometrial tissue breakdown and bleeding. followed by hemostasis and repair. Abnormalty of this process at any stage may result in changes in the quantity of menstual blood 1055.

Excessive menstrual blecding is an important reason for consultation to general practitionets. The volume of menstrual blood lost is important, since excessive bleeding may lead to inon deficiency anemia, and in severe cases may neoessitate bysterectomy. Menstrual bleeding is considered excessive if greater than $80 \mathrm{ml}$ and constitutes objective menomigi?

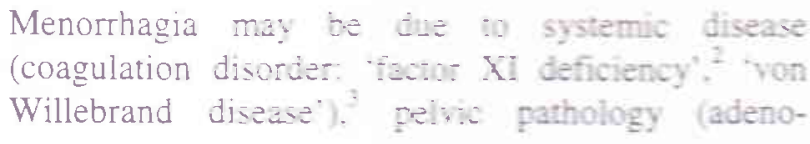

Department of Histology, Faculty of ifedicte, University of

Indonesia, Jakarta, Iridoresia myosis, fibromyomata. endometrial polyp, endometriosis) contraceptive use (intra-uterine device) or dysfunctional uterne bleding (DUB). Forty to $60 \%$ of menorriagia cases is atributed to DUB. ${ }^{5}$ DUB is a diagrosis of exclusion. and refers to excessively hady prolonged or frequent bleeding (most commonly hะa:y. ie. menorrhagia) which is not caused by gregninc: or any recognizable pelvic or systemic disade.

This review will discuss the mechanism of normal mensiruation and factors associated with menorrhagia.

\section{MECHANISM OF NORMAL MENSTRUATION}

Nomal menstruation is triggered by the fall in cestradiol and progesteron concentrations following iuteolysis. It is preceeded by endometrial tissue breakdown and bleeding. and followed by hemostasis, repair and angiogenesis. These processes are largely coniroiled by local factors (Figure 1). 


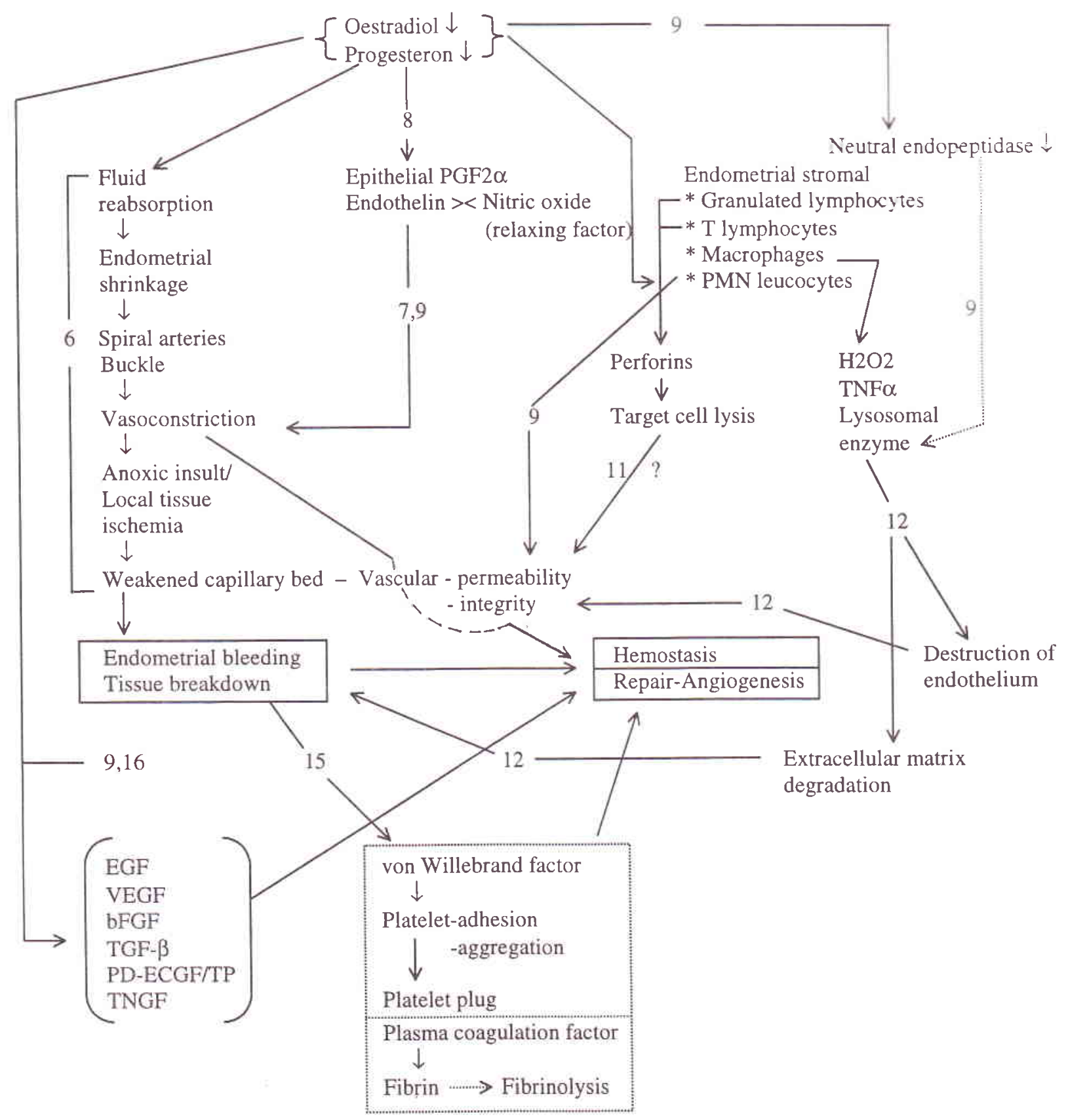




\section{Endometrial tissue breakdown and bleeding}

Markee (as cited from Brenner, 1996) noted that the first and most reliable sign of impending menstruation was a slowing of blood flow in the upper endometrial regions, accompanied by a reduction in endometrial thickness due to fluid reabsorption. This shrinkage, or premenstrual regression, began 2 days before bleeding and continued throughout the bleeding episode. The second key event was compression of the spiral arteries. These coiled vessels buckled to accommodate shrinkage of the endometrium. As a consequence, blood flow through these vessels was greatly reduced. The third event was an extensive vasoconstriction of the spiral arteries which further reduced blood flow to the upper zones. The vascular stasis induced by such compression and vasoconstriction led to anoxic insult that weakened the capillary bed. ${ }^{6}$

Induction of local tissue ischemia by a prolonged vasoconstriction of the end arterioles of the spiral arteries is possibly induced by specific prostaglandins secreted during the second half of the ovarian cycle, which exerts paracrine influence. Secretion of prostaglandin, particularly PGF $2 \alpha$ by the epithelial cells, is hypothesized to be due to progesterone withdrawal at the end of the cycle. ${ }^{8}$ Furthermore. a consequent rise in tissue concentrations of locally synthesized endothelins may be responsible for the vasoconstriction leading to the onset of tissue breakdown."

The role of lymphocytes, macrophages and polymorphonuclear leucory tes in tissue breakdown

In the normal menstrual cycle there is a subsantial pre-menstrual increase in enfomenial stromal granulated lymphowtes T I.matowes and macrophages, while polymorghonded ledorotes only appear in uterine tissues at the onser of mensunution."

Polymorphonuclear leucowey are diten lowated near blood vessels in the endometrum, where they may influence vascular permeability and integrity. The influx of leucocytes into human endometrium is influenced by changes in circulating (or tissue) steroid concentrations, especially progesterone and progestogen, and small populations of these cells have varying oestradiol and/or progesterone receptor positivity.

Granulated lymphocyies are located near to endometrial blood vessels in the basal zone. The granules of a variety of cytotoxic lymphocytic cells contain perforins that mediate target cell lysis. However it is not clear, if granulated lymphocytes ever mediate such toxicity against blood vessels locally. ${ }^{11}$

Macrophages can be cytotoxic to tissue by release of $\mathrm{H} 2 \mathrm{O} 2$, TNF alfa, and various lysosomal enzymes. ${ }^{11}$ The secretion of hydrolytic (lysosomal) enzymes into the extracellular space is a mechanism that could initiate endometrial bleeding, either directly by dissociation or destruction of endothelial cells or perivascular tissue, or indirectly by degradation of the extracellular matrix. ${ }^{12}$

\section{The role of proteolytic enzymes and its inactivator}

Several proteolytic enzimes have been implicated in tissue breakdown. They are present in the lysosomes (aspartic lysosomal proteinase cathepsin D and lysosomal cysteine proteases), or secreted either at the cell surface or in extracellular matrices or fluids (metallo- and serine proteinases). The nonsedimentable fraction of lysosomal enzymes from endometrial homogenates has been reported to increase from about $25 \%$ at the proliferative phase to about $50 \%$ at the late secretory phase. ${ }^{12}$

The matrix metalloproteinases (MMP: collagenase, gelatinase and stromelysisn) are capable of degrading most matry proteins. including interstitial collagens, basement membrane collagen. proteoglycans, laminin and fibronectin Matrix metalloproteinases are expressed in the stromal and epithelial cells of endometrum. ${ }^{6}$ However. decreasing concentrations of progesterone result in a fall in the endometrial tussue concentration of neutral endopeptidase (a glyosylated zine metallopeptidase capable of inactivang a number of endocrine and paracrine peptide).

Altogether, these events leads to tissue shedding. The desquamative process probably follows a topographic sequence and the process might not have reached the same stage in each segment of the uterine cavity. There is still controversy about the extent of tissue shedding at menstruation. Some investigators stated that at no time during menstruation was there extensive denudation of surface epithelium. The largest breaks were not more than $2 \mathrm{~mm}$ in diameter and most were less than $100 \mathrm{um}$. Some other stated that most part of surface lining epithelium are shed, with only the epithelium at the glandular stumps left 
and, adjacent to it, naked endometrial stroma forming the surface. However, isles of non-shed endometrium may be preserved within the fundal cavity. ${ }^{14}$

\section{Hemostasis, repair and angiogenesis}

The normal hemostatic process can be divided into three phases. The first phase, primary hemostasis, consist of platelet adhesion and aggregation. After vascular injury, proteins in the subendothelium are exposed and promote platelet adhesion. Platelet adhesion is uniquely dependent on von Willebrand factor, a plasma protein that serves as a molecular bridge between components of the vessel wall and the platelet glycoprotein $\mathrm{Ib} / \mathrm{IX}$ receptor. Activation of adherent platelets promotes additional platelet recruitment, culminating in the formation of the platelet plug. ${ }^{15}$

In the next phase, secondary hemostasis, the plasma coagulation factors are sequentially activated, which lead to fibrin formation and cross-linking. These reactions take place primarily on the surface of activated platelets and are essential in maintaining the stability of the initial platelet plug. Finally, in the final phase, fibrinolysis occurs. The fibrin clot undergoes an orderly process of degradation. ${ }^{15}$

In addition, hemostasis relies to a considerable extent on the timely and adequate constriction of bleeding vessels. These events are controlled by prostaglandins and endothelins, which appears to be powerful vasoactive substances, and their production is regulated by circulating oestrogen and progesterone concentrations. ${ }^{9}$

Endothelins, located predominantly at the endometrialmyometrial junction, act as powerful vasoconstrictors. Tissue endothelin concentration may interact with relaxing factors such as endothelium-derived relaxing factor (EDRF), also known as nitric oxide.

For menstrual bleeding to cease, there must be repair of the epithelium and vascular endothelium initiated from the remaining basal layers of endometrium. In addition, local factors are likely to play a central role in this reparative and angiogenesis process. It is suggested that cells or cellular products from residual areas of the functional layer are important in normal endometrial remodelling and repair. Regeneration begins within 24 hours and is complete within 4-5 days of the onset of menstruation. Growth factors in the endometrium may be crucial to the speed and efficacy of the reparative and angiogenesis process. These growth factors are: epidermal growth factor (EGF), transforming growth factors (e.g. TGF-beta). platelet-derived endothelial growth factor/thymidine phosphorylase (PD-ECGF/TP), tumor necrosis growth factors, and vascular endothelial growth factor (VEGF) ${ }^{16}$ The secretion of potent endometrial growth factors, such as VEGF, basic fibroblast growth factor (bFGF) and EGF, is influenced by ovarian steroid hormones ${ }^{9,16}$ However, it is unclear how important any direct effect of oestradiol may be on epithelial proliferation and repair.

\section{FACTORS ASSOCIATED WITH MENORRHAGIA}

\section{Endometrial bleeding associated factor (ebaf)}

A novel human gene, endometrial bleeding associated factor (ebaf), was reported. This gene is located on human chromosome 1 at band q42.1. ${ }^{17}$ In normal human endometrium, this gene is transiently expressed before and during menstrual bleeding in the stroma without any significant expression in the endometrial glands or endothelial cells. In endometrium strong expression of this gene is associated with abnormal endometrial bleeding." Therefore. ebaf might have a role in menorrhagia.

\section{Migratory leucocytes, macrophages and mast cells}

Migratory leucocytes, macrophages. and mast cells may contribute to the mechanism of excessive blood loss. An excessive leucocyte infilltrate has been associated with the copper intra-uterine device. one of the several causes of menorrhagia. Macrophages may release platelet-activating factor (PAF) and prostaglandin E, both of which are potent vasodilators, and mast cells may secrete a range of vasoactive substances, all of which could augment menstrual blood loss. Mast cells may also play a role in the defective haemostatic process. They have been shown to degranulate pre-menstrually to secrete heparin, histamin and other substances. Heparin stimulates endometrial fibrinolysis via the secretion of tissue plasminogen activator, and histamin causes endothelial cell contraction, creating gaps between vascular endothelial cells to allow increased vascular fluid loss. In dysfunctional uterine bleeding, the secretion of heparin-like substances has been showed to be increased. ${ }^{9}$ 


\section{Lysosomal enzymes}

Endometrial lysosomal enzyme activity in women with ovulatory dysfunctional uterine bleeding and menorrhagia secondary to intrauterine device (IUD) use is increased. Excessive or prolonged tissue degradation due to lysosomal enzyme activity such as matrix metalloproteinases could result in increased or prolonged menstrual bleeding. ${ }^{9}$

\section{Prostaglandins and endothelins}

Ovulatory dysfunctional bleeding is associated with a shift in the ratio of endometrial vasoconstricting PGF $2 \alpha$ to vasodilatory PGE2, and an increase in the total concentration of prostaglandins. There is also an increased capacity for myometrial generation of prostacyclin (PGI2) from endometrial precursors. PGI2 is a vasodilatory prostaglandin and a potent inhibitor of platelet aggregation. Successful treatment of ovulatory dysfunctional uterine bleeding with prostaglandin sythetase inhibitors leads to a reduction in endometrial concentrations of PGF2 $\alpha$ and PGE2, and inhibits the binding of PGE to its receptor. In addition, in women with menorrhagia, there is an increase in prostaglandin receptor concentrations: Therefore, endometrial tissue may be more responsive to the action of the increased vasodilatory protaglandins.

Endothelin has potent vasoconstrictor and growth factor properties, and has been proposed to have a paracrine role in the regulation of uterine blood flow. In menorrhagia, endothelin is reduced in glandular epithelium. ${ }^{18}$ Its concentration in the endometrium of women with ovulatory dysfunctional uterine bleeding may be depressed substantially. Disrupted patterns of endothelin production may prolonged or increased menstrual blood loss. ${ }^{9}$ In addition, its metabolizing enzyme, neutral neuropeptidase, is increased in the glandular epithelium of women with menorrhagia. Therefore, endothelin and neutral neuropeptidase might be a factor in menorrhagia. ${ }^{18}$

\section{Growth factor receptor}

Angiogenic growth factors play a critical role in the cyclic growth and vascularization of normal endometrium. Fibroblast growth factor receptor-1 (FGF-R1) colocalized with basic fibroblast growth factor (FGF-2). FGF-RI is markedly reduced or absent in women with menorrhagia throughout the cycle relative to that of normal cycling women. This suggests that FGF-R1 is critical for endometrial 'maturation' and regeneration of the normal endometrium following menstruation. ${ }^{19}$

\section{Fibrinolysis and hemostatic process}

Active fibrinolysis within the normal endometrium and uterine cavity at menstruation prevents organized clot formation and the development of intrauterine adhesions. Ovulatory dysfunctional uterine bleeding is associated with an increased in endometrial fibrinolysis, and an increased concentration of tissue plasminogen activator. Overactivation of these fibrinolytic mechanism may unbalance the haemostatic system, and may result in excessive blood loss. In addition, quantitative or qualitative defect in either phase of hemostatic process is important to consider when evaluating women with menorrhagia.

\section{Changes in endometrial blood flow}

In women with ovulatory dysfunctional uterine bleeding there is a significant increase in endometrial blood flow compared with normal, and this is seen during the period of raised oestradiol secretion in the follicular phase. There is a subsequent decrease in flow in the secretory phase, with a late premenstrual rise equivalent to that seen in normal cycles. It is unclear whether the increased endometrial flow in the follicular phase has any direct influence on menstrual blood loss. ${ }^{9}$

\section{CONCLUSION}

The mechanism of normal menstruation is preceded by endometrial tissue breakdown and bleeding, and followed by hemostasis and repair. Excessive menstrual blood loss might be due to the abnormality in the the role of leucocytes, macrophages and mast cells. in the concentration of lysosomal enzymes. prostaglandins and its receptors, and endothelins. Furthermore it may be due to overactivation of endometrial fibrinolysis mechanism and changes in endometrial blood flow.

\section{REFERENCES}

1. Rees MCP. Factors controlling menstrual blood volume. In: d'Arcangues, Fraser IS, Newton FJR, Odlind V, editors. Contraception and mechanism of endometrial bleeding. New york: Cambridge; 1990:117-39.

2. Kadir RA, Economides DL, Lee CA. Factor XI deficiency in women. Am J Hematol 1999;60:48-54. 
3. Kouides PA. Females with von Willebrand disease: 72 years as silent majority. Haemophilia 1998;4:665-76.

4. Pepperell RJ. Management of dysfunctional uterine bleeding in the reproductive age. In: Saifuddin AB, Affandi B, Wiknjosastro GH, editors. Women's health. Recent advances in the Asia-Oceania region. Jakarta: Bina Pustaka Sarwono Prawirohardjo; 1995. p145-7.

5. Fraser IS. Treatment of menorrhagia. Baillere's Clin Obstet Gynecol 1989;3:391-402.

6. Brenner RM, Rudolph L, Matrisian L, Slayden OD. Nonhuman primate models: artificial menstrual cycles, endometrial matrix metalloproteinases and s.c. endometrial grafts. In: Findlay J, Affandi B, editors. Menstrual disorders and progestin contraception. Human reproduction 1996, 11 suppl 2:150-64.

7. Rice-Evans C, Cooke B. Oxygen radicals, bleeding and tissue injury. In: d'Arcangues, Fraser IS, Newton FJR, Odlind V, editors. Contraception and mechanism of endometrial bleeding. New York: Cambridge; 1990. p411-30.

8. Findlay JK, Cherny RA, Salamonsen LA. Paracrine interactions amongst cells of the endometrium. In: d'Arcangues, Fraser IS, Newton FJR, Odlind V, editors. Contraception and mechanism of endometrial bleeding. New york; Cambridge; 1990. p253-65.

9. Fraser IS, Hickey M, Song J-Y. A comparison of mechanisms underlying disturbances of bleeding caused by spontaneous dysfunctional uterine bleeding or hormonal contraception. In: Findlay J, Affandi B, editors. Menstrual disorders and progestin contraception. Human Reproduction 1996, 11 suppl 2:165-78.

10. Kamat BR, Issacson PG. The immunocytochemical distribution of leucocyte subpopulations in human endometrium. Am J Pathol 1987;127:66-73.

11. Clark DA, Daya S. Macrophages and other migratory cells in endometrium: relevance to endometrial bleeding. In: d'Arcangues, Fraser IS, Newton FJR, Odlind V, edotors. Contraception and mechanism of endometrial bleeding. New york: Cambridge; 1990. p363-382.
12. Cornillie FJ, Brosens IA, Marbaix E, Vael TH, Baudhuin P, Courtoy PJ. A biochemical study of lysosomal enzymes in control and levonorgestrel-treated human endometria: analysis of total activity and evidence for secretion. In d'Arcangues, Fraser IS, Newton FJR, Odlind V, editors Contraception and mechanism of endometrial bleeding New york: Cambridge; 1990 p383-410.

13. Eeckhout Y. Tissue breakdown. In: d'Arcangues. Fraser IS, Newton FJR, Odlind V. editors. Contraception and mechanism of endometrial bleeding vew york: Cambridge; 1990. p432-40

14. Ludwig H, Metzger H, Frauli M. Endornetrum: t:ss_a remodelling and regeneration. In: d Arcangues. Frazer IS. Newton FJR, Odlind V, editors. Contraception ans mechanism of endometrial bleeding. New york: Cambridge; 1990. p441-66.

15. Ewenstein BM. The pathophysiology of bleeding disorders presenting as abnormal uterine bleeding Am J Obstet Gynecol 1996;175:770-7.

16. Smith SK. Angiogenesis, vascular endothelial growth factor and the endometrium. Hum Reprod Lputate 1998:4:509-19.

17. Kothapalli R, Buyuksai I, Wu SQ, Chegini N, Tabibzadeh $S$. Detection of ebaf, a novel human gene of the transforming growth factor beta superfamily association of gene expression with endometrial bleeding. J Clin Invest 1997;99:2342-50.

18. Marsh MM, Malakooti N, Taylor NH, Findlay JK. Salamonsen LA. Endothelin and neutral endopeptidase in the endometrium of women with menorrhagia. Hum Reprod 1997;12:2036-40.

19. Sangha RK, Li XF, Shams M, Ahmed A. Fibroblast growth factor receptor- 1 is a critical component for endometrial remodeling: localization and expression of basic fibroblast growth factor and FGF-R1 in human endometrium during the menstrual cycle and decreased FGF-R1 expression in menorrhagia. Lab Invest 1997;77:389-402 